\title{
Relationship between Work Climate and Physical Workload with Work- Related Fatigue
}

\section{Hubungan antara Iklim Kerja dan Beban Kerja Fisik dengan Kelelahan Kerja}

\author{
Mustofani, Endang Dwiyanti \\ Department of Occupational Safety and Health, Faculty of Public Health, Universitas Airlangga \\ Campus C Mulyorejo, Surabaya, East Java, Indonesia 60115
}

\begin{abstract}
Introduction: Work-related fatigue is a common problem in the workplace that must be solved because it has an impact on the occurrence of workplace accidents, reduces productivity and affects workers' health. A survey conducted by the National Safety Council on 2010 workers in 2017 stated that $69 \%$ of them experienced workrelated fatigue and $13 \%$ of them could be attributed to workplace accidents. Other studies conducted by O'Neill and Panuwatwanich in 2013 stated the loss that could arise due to work-related fatigue is averaged around \$ 1,000 /week. The purpose of this study was to determine the relationship between work climate and physical workload with work-related fatigue on workers in the $5^{\text {th }}$ warehouse of fabrication area of Bangun Sarana Baja Company. Metods: This study is an observational analytic with a cross-sectional approach with 30 respondents who were randomly selected using the simple random sampling method. Measurements of the work climate used heat stress apparatus by calculating the Wet Bulb Globe Temperature, and measurement of physical workload is carried out by observations referring to Indonesian national standard No. 7269 in 2009. Meanwhile, work-related fatigue is measured objectively by using reaction timer. Results: This study indicates the average work climate is exceeding TLV $\left(28.4^{\circ} \mathrm{C}\right)$, and the majority of workers got a moderate physical workload $(53.3 \%)$ and experience mild work-related fatigue $(50 \%)$. Conclusion: There was no relation between work climate and work-related fatigue ( $\mathrm{p}$-value $=0.192$ ) and there was a significant relationship between physical workload and work-related fatigue $(\mathrm{p}$-value $=0.028, \mathrm{r}=0.400)$.
\end{abstract}

Keywords: physcal workload, work climate, work-related fatigue

\begin{abstract}
ABSTRAK
Pendahuluan: Kelelahan kerja adalah masalah umum yang ada di tempat kerja yang harus diselesaikan karena dapat berdampak pada terjadinya kecelakaan di tempat kerja, menurunkan produktivitas dan berdampak pada kesehatan pekerja. Sebuah survei yang dilakukan oleh National safety Council pada pekerja 2010 tahun 2017 menyatakan $69 \%$ dari mereka mengalami kelelahan kerja dan 13\% diantaranya dapat dikaitkan dengan terjadinya kecelakaan kerja. Studi lain yang dilakukan oleh O'Neill dan Panuwatwanich pada 2013 menyatakan kerugian yang bisa timbul karena kelelahan kerja rata-rata mencapai sekitar \$1.000 /minggu. Tujuan dari penelitian ini adalah untuk mengetahui hubungan antara iklim kerja dan beban kerja fisik dengan kelelahan kerja pada pekerja di gudang ke 5 area fabrikasi PT. Bangun Sarana Baja. Metode: Penelitian ini merupakaan penelitian observasional analitik dengan pendekatan cross-sectional. Jumlah sampel dalam penelitian ini adalah 30 responden yang dipilih secara acak menggunakan metode simple random sampling. Pengukuran iklim kerja menggunakan heat stress apparatus dengan menghitung Indeks suhu basah dan bola, pengukuran beban kerja fisik dilakukan dengan observasi dengan mengacu pada standar nasional Indonesia No. 7269 tahun 2009. Sementara itu, kelelahan kerja diukur secara objektif dengan menggunakan reaction timer. Hasil: Penelitian ini menunjukkan rata-rata iklim kerja melebihi $N A B\left(28,4{ }^{\circ} \mathrm{C}\right)$, mayoritas pekerja mendapatkan beban kerja fisik sedang (53,3\%) dan mengalami kelelahan kerja tingkat ringan (50\%). Simpulan: Tidak ada hubungan antara iklim kerja dan kelelahan kerja (p-value =0,192) dan ada hubungan yang signifikan antara beban kerja fisik dan kelelahan kerja ( $p$-value $=0,028, r=0,400)$.
\end{abstract}

Kata kunci: beban kerja fisik, iklim kerja, kelelahan kerja

\section{Author for Correspondence:}

Mustofani

Email: ucup.mbuh@gmail.com 


\section{INTRODUCTION}

Indonesia is one of the largest countries in Southeast Asia that is rich in biodiversity and has a fairly stable economy. Throughout 2015, the Indonesian economy grew by $5.04 \%$. This growth was achieved in all industry sectors including manufacturing. In 2011, the number of large and medium scale of companies in manufacturing industry reached 23.370 units with 4.6 million workers and continued to grow until 2015 which reached 26.322 units to 5.2 million workers (Statistic Indonesia, 2016).

Workers as part of resources in production must complete a given task demands. In completing the task, the worker takes an effort to achieve these goals (Safe Work Australia, 2013). Therefore, workers cannot be separated from the risk of work-related fatigue. Work-related fatigue can be defined as a feeling of fatigue and a reduce of alertness as the result of a prolonged activity. Work-related fatigue may occur due to an imbalance condition between work capacity and task demand (Tarwaka, Bakri and Sudiajeng, 2004).

Work-related fatigue is a common problem in the workplace. The prevalence of work-related fatigue ranges from $10 \%$ to $40 \%$ (Ho et al., 2013). It is very important to be solved immediately because it has an impact on the occurrence of workplace accidents. Workrelated fatigue also has decreased the productivity (Maurits, 2010). Based on a study conducted on 28.902 workers in the United States, the prevalence of fatigue can reach $37.9 \%$ and lose an average of 4.1 productive hours in each week (Ricci et al., 2007). Based on a survey, $69 \%$ of the 2010 workers experiencing work-related fatigue and $13 \%$ of them can be associated with workplace accidents (National Safety Council, 2017). Based on the results of another study, the losses due to work-related fatigue experienced by the dam project workers in Queensland reached averaged of \$ 966 or around \$ 1,000 per week (O'Neill and Panuwatwanich, 2013).

In addition, work-related fatigue in the long term will also have an impact on the workers' health. Some of the risks that may result from prolonged work-related fatigue are heart disease, diabetes, high blood pressure, gastrointestinal disorders, lower fertility, anxiety, and depression (Safe Work Australia, 2013).
Based on the ergonomics balance theory, work-related fatigue can occur due to an imbalance between work capacity and task demand. One of the factors that can cause workrelated fatigue and is included in the task demand is the work climate (Tarwaka, Bakri and Sudiajeng, 2004).

Work climate can be defined as the result of combination between temperature, humidity, air movement speed and heat radiation. Work climate has a contribution in influencing the workers' performance in the workplace. The heat energy emitted by a heat source that goes into the work environment becomes an additional workload for workers. This additional workload is called heat stress. According to Suma'mur (2013), the effect of heat stress will result in the loss of fluid in the body, resulting in the onset of work-related fatigue. The hot environment also has a bad influence on the workers' body. According to research conducted by Krisanti (2011), there is a significant relationship between the hot environment and work-related fatigue with a positive correlation coefficient. After measuring the temperature at the production area in furniture industry in Surakarta, data of an average temperature Wet Bulb Globe Temperature (WBGT) amounted to $31.24^{\circ} \mathrm{C}$ were obtained. Total of 30 workers $(66.6 \%)$ who were exposed to the heat environment experienced weight work-related fatigue level, $23.3 \%$ workers experienced moderate work-related fatigue level and $10 \%$ of others experienced mild work-related fatigue level. Other studies have also suggested the same thing that the group of workers who were exposed to heat environment experienced weight work-related fatigue levels higher $(35.7 \%)$ than the group of workers who were not exposed to the heat environment (19\%) (Marif, 2013).

Other factors included in the task demand that can cause work-related fatigue is physical workload (Tarwaka, Bakri and Sudiajeng, 2004). Physical workload can be interpreted as a difference between the capacity or ability of workers with the demands of work that must be faced by workers. Physical workload that exceeds the work capacity of workers will have an impact on the incidence of overstress conditions that led to the occurrence of workrelated fatigue (Tarwaka, Bakri and Sudiajeng, 2004). The physical workload can be defined as the difference between the capacity or ability of workers and the task demands of the job that must be faced (Tarwaka, 2013). A study 
conducted on industry workers of melinjo chips in Indramayu mentioned that there is a strong relationship between physical workload and work-related fatigue with a relative risk (RR) 3.750 which means the ones who work with heavy physical workload would risk 3,750 times higher of experiencing work-related fatigue than those who get a mild physical workload (Ahmad and Amanatun, 2015).

The purpose of this study is to determine the relationship between work climate and physical workload with work-related fatigue on workers in the $5^{\text {th }}$ warehouse of fabrication areas of Bangun Sarana Baja Company.

\section{METHODS}

This research was conducted from March to December 2018. Data collection was conducted in October 2018. This study is observational analytic with a cross-sectional approach. The population in this study was 43 workers in the $5^{\text {th }}$ warehouse of fabrication area of Bangun Sarana Baja Company. The number of samples is determined using the formula of (Lemeshow et al., 1997) as follows :

$$
\begin{aligned}
& \mathrm{n}=\frac{\mathrm{N} \cdot \mathrm{Z}_{1-\alpha / 2 \cdot \mathrm{p} \cdot \mathrm{q}}^{\mathrm{d}^{2}(\mathrm{~N}-1)+\mathrm{Z}_{1-\alpha / 2}^{2} \mathrm{p} \cdot \mathrm{q}}}{n=\frac{43 \cdot 1,96^{2} \cdot 0,5 \cdot(0,5)}{0,1^{2}(43-1)+1,96^{2} \cdot 0,5(0,5)}} \\
& n=\frac{41,2972}{1,3804} \\
& n=29.9168357 \text { or rounded to } 30
\end{aligned}
$$

Information:

$$
\begin{array}{ll}
\mathrm{n} & : \text { Number of samples } \\
\mathrm{N} & : \text { Total population } \\
\mathrm{p} & : \text { Approximate proportion }(0.5) \\
\mathrm{q} & : 1-\mathrm{p} \\
\mathrm{Z} 1-\alpha / 2 & : \text { Statistics } \mathrm{Z}(\mathrm{Z}=1.96 \text { for } \alpha \text { of } 5 \%)
\end{array}
$$

Based on these calculations, the resulting number of samples of this study was 30 workers. Workers were then randomly selected by simple random sampling method. The researcher made a list of workers in warehouse 5 area fabrication and then made a lottery to determine who was selected in this study.

The independent variables in this study were the work climate and physical workload.
The dependent variable in this study was workrelated fatigue.

Work climate was measured using heat stress apparatus by calculating the Wet Bulb Globe Temperature (WBGT) for the indoor environment. The the formula used to measure WBGT for indoor environment can be seen below:

$\mathrm{WBGT}=0,7 \mathrm{WB}+0,3 \mathrm{GT}$

Information:

WBGT : Wet Bulp Globe Temperature

WB : Wet Bulp

GT : Globe Temperature

This measurement was chosen because this method is the simplest, most commonly used method, and it is recommended by National Institute of Occupational Safety and Health (NIOSH), The Occupational Safety and Health Administration (OSHA), American Conference of Governmental Industrial Hygienists (ACGIH) and International Organization for Standardization (ISO) because it is more appropriate to assess a hot work environment (Moeljosoedarmo, 2008; Anna, 2011). Measurements were taken at 11:00 with cloudy weather conditions. The vents used in the workplace were natural ventilation. The Threshold Value limit (TLV) of this variable is referring to the (Minister of Manpower of the Republic of Indonesia, 2018). The place of measurement was conduceted in three places. These places were chosen because they represented the type of work in the $5^{\text {th }}$ warehouse of fabrication area of Bangun Sarana Baja Company (assembly, welding, and grinding). The measurement point was selected at the place closest to the source of the heat where a lot of work activities were carried out.

Physical workload was measured by observation with an instrument based on the Indonesian National Standard (SNI) No. 7269 in 2009. Observations physical workload was carried out for 4 hours and it focused on job category, the position of work and working duration of every task. Observations were made to determine the estimated caloric needs of workers every hour including basal metabolism. The calculation results will be adjusted to the workload category to be mild physical workload (100 kcal to $200 \mathrm{kcal} /$ hour), moderate physical workload (200 kcal to $350 \mathrm{kcal} /$ hour), and heavy 
physical workload (350 kcal to $500 \mathrm{kcal} /$ hour). Physical workload variables examined in this study were the pure physical workload received by workers. Researchers did not incorporate the additional workload into this variable.

Measurement of work-related fatigue was performed at 10:00 using reaction timer. Workers were given a certain amount of stimulus and were recorded then the resulting average reaction time workers was calculated. The category of work-related fatigue was divided into several levels according to Maurits (2010) which were normal ( 150 to 240 millisecond), mild work-related fatigue $(>240$ to $<410$ milliseconds), moderate work-related fatigue (410 to $<580$ milliseconds), and weight workrelated fatigue ( $\geq 580$ milliseconds).

The collected data were then processed and statistically tested by Spearman correlation test with $\alpha=5 \%(0.05)$.

\section{RESULTS}

\section{General Overview of Respondents}

Table 1. Characteristics Workers In The $5^{\text {th }}$ Warehouse Of Fabrication Area Bangun Sarana Baja Company In 2018

\begin{tabular}{crrrr}
\hline $\begin{array}{c}\text { Characteristics } \\
\text { (Year) }\end{array}$ & Min & Max & Mean & Std. dev \\
\hline $\begin{array}{c}\text { Age } \\
\text { Length of } \\
\text { working }\end{array}$ & 20 & 54 & 35.30 & 9.433 \\
\hline
\end{tabular}

Based on the research results, the respondents in this study were 30 workers and all of them were male. The majority of respondents were between of $36-45$ years old with the majority length of work between 6 - 10 years. The general overview about characteristics of respondents can be seen in the Table 1 .

\section{Univariate Analysis}

\section{Work Climate}

Work climate is the result of a combination of temperature, humidity, air movement speed and radiation heat with the level of heat dissipation from the body of the workforce. Work climate was measured using WBGT (Wet Bulb Globe Temperature) and adjusted to the (Minister of Manpower of the Republic of Indonesia, 2018). The measurement results of working climate can be seen the Table 2.

Table 2. Work Climate Condition in the $5^{\text {th }}$ Warehouse of Fabrication Area of Bangun Sarana Baja Company in 2018

\begin{tabular}{lclc}
\hline \multicolumn{1}{c}{ Area } & $\begin{array}{c}\text { WBGT } \\
\left({ }^{\circ} \mathbf{C}\right)\end{array}$ & Workload & $\begin{array}{c}\text { Informatio } \\
\mathbf{n}\end{array}$ \\
\hline Gerinding & 28.0 & Moderate & $\leq \mathrm{TLV}$ \\
Assembling & 28.8 & Moderate & $>\mathrm{TLV}$ \\
Welding & 29.0 & Moderate & $>\mathrm{TLV}$ \\
\hline
\end{tabular}

\section{Physical Workload}

Physical workload measurement results can be seen in Table 3 . The majority of workers get moderate physical workload $(53.3 \%)$.

Table 3. Physical Workload Of Workers In The $5^{\text {th }}$ Warehouse Of Fabrication Area Bangun Sarana Baja Company In 2018

\begin{tabular}{ccc}
\hline Physical Workload & N & \% \\
\hline Mild & 11 & 36.7 \\
Moderate & 16 & 53.3 \\
Heavy & 3 & 10 \\
\hline Total & 30 & 100 \\
\hline
\end{tabular}

\section{Work-related Fatigue}

Work-related fatigue was measured using a timer reaction. Work-related fatigue measurement results can be seen in Table 4. The majority of workers experienced work-related fatigue in the mild level (50\%). There were no workers who experienced work-related fatigue in heavy level.

Table 4. Work-Related Fatigue Of Workers in the $5^{\text {th }}$ Warehouse of Fabrication Areas of Bangun Sarana Baja Company in 2018

\begin{tabular}{ccc}
\hline $\begin{array}{c}\text { Work-related Fatigue } \\
\text { level }\end{array}$ & $\mathbf{n}$ & $\boldsymbol{\%}$ \\
\hline Normal & 12 & 40 \\
Mild & 15 & 50 \\
Moderate & 3 & 10 \\
\hline Total & 30 & 100 \\
\hline
\end{tabular}




\section{Bivariate Analysis}

This analysis was done by Spearman correlation test with $\alpha=5 \%(0.05)$. Based on Table 5, it can be concluded that the relationship between work climate and work-related fatigue produces $p$-value $(0.192)$ which is higher than the value of $\alpha(0.05)$. It means there is no significant relationship between work climate with work-related fatigue.

The relationship between physical workload and work-related fatigue produces $\mathrm{p}$ value $(0.028)$ which is smaller than the value of $\alpha(0.05)$. It means there is a significant relationship between physical workload with work-related fatigue. The coefficient correlation between the two variables is positive with a medium level (0.400); thus, the higher the physical workload given to the workers, the higher the increase of work-related fatigue level.

\section{DISCUSSION}

\section{Work Climate}

Work climate is one factor that is included in the environmental characteristic of task demand factors. If the task demand is greater than work capacity, it will lead to work-related fatigue (Tarwaka, Bakri and Sudiajeng, 2004),

The results showed no significant relationship between work climate and workrelated fatigue in the $5^{\text {th }}$ warehouse of fabrication area of Bangun Sarana Baja Company. This result is similar to studies conducted on workers at Tiga Pilar Sejahtera Food Company (Ristiyanto, 2009). The furniture workers (Setyowati, Shaluhiyah and Widjasen, 2014), in the workers packing area in X Company (Adi, Suwondo and Lestyanto, 2013) and the workers of Apac Inti Corpora Company (Herusasongko, Sutomo and Sudibyakto, 2012) stated that there was no significant relationship between work climate with work-related fatigue.

As a result of the inclusion of heat energy in the work environment, there will be a change in the work climate. Working climate change will result in heat (heat stress) that will be received by workers and will be a risk of negative impact on workers. However, the response of the body of every worker against a hot environment will be different (Moeljosoedarmo, 2008).

Workers in the welding area (welder) have already used the complete personal protective equipment (PPE) as a requirement of the company. The personal protective equipments which were used to reduce the exposure of hot environment were gloves, google helmet, and welding apron. Therefore, exposure to heat had been minimized. Moreover, workers were provided with a source of drinking water in gallons along the fabrication area, including in the 5th warehouse. A worker breaks occasionally and fulfills fluid intake with the water provided. According to Moeljosoedarmo (2008), one of the controls that can be done to avoid the bad effect of heat stress is to replace the loss of fluids during work. The liquid that enters replaces the liquid that is released in the form of sweat in an effort to cool the body. Appropriate beverage placements will indirectly encourage workers to meet their liquid needs.

The working climate measurements were carried out on October 16, 2018 starting at 11:00 with cloudy weather conditions. The average temperature in the $5^{\text {th }}$ warehouse of fabrication area Bangun Sarana Baja Company was $28.4^{\circ} \mathrm{C}$ and the maximum temperature reached $29.0^{\circ} \mathrm{C}$. The maximum temperature was not much

Table 5. The Relationship Between Work Climate And Physical Workload With Work-Related Fatigue Of Workers In The $5^{\text {th }}$ Warehouse Of Fabrication Areas Bangun Sarana Baja In 2018.

\begin{tabular}{|c|c|c|c|c|c|c|c|c|c|c|c|}
\hline & & \multicolumn{6}{|c|}{ Work-related Fatigue } & \multirow{2}{*}{\multicolumn{2}{|c|}{ Total }} & \multirow{3}{*}{$P$-value } & \multirow{3}{*}{$\begin{array}{c}\text { Correlation } \\
\text { coefficient }\end{array}$} \\
\hline \multicolumn{2}{|c|}{ Variable } & \multicolumn{2}{|c|}{ Normal } & \multicolumn{2}{|c|}{ Mild } & \multicolumn{2}{|c|}{ Moderate } & & & & \\
\hline & & $\mathbf{n}$ & $\%$ & $\mathbf{n}$ & $\%$ & $\mathbf{n}$ & $\%$ & $\mathbf{N}$ & $\%$ & & \\
\hline \multirow{4}{*}{$\begin{array}{l}\text { Physical } \\
\text { Workload }\end{array}$} & Mild & 7 & 63.7 & 3 & 27.3 & 1 & 9 & 11 & 100 & \multirow{4}{*}{0.028} & \multirow{4}{*}{0.400} \\
\hline & Moderate & 6 & 37.5 & 9 & 56.3 & 1 & 6.2 & 16 & 100 & & \\
\hline & Heavy & 0 & & 1 & 33.3 & 2 & 66.7 & 3 & 100 & & \\
\hline & Total & 13 & & 13 & & 4 & & 30 & & & \\
\hline \multirow{3}{*}{$\begin{array}{c}\text { Work } \\
\text { climate }\end{array}$} & $\leq \mathrm{TLV}$ & 7 & 58.4 & 4 & 33.3 & 1 & 8.3 & 12 & 100 & \multirow{2}{*}{0.192} & \multirow{2}{*}{-} \\
\hline & $>\mathrm{TLV}$ & 6 & 33.3 & 9 & 50 & 3 & 16.7 & 18 & 100 & & \\
\hline & Total & 13 & & 13 & & 4 & & 30 & & & \\
\hline
\end{tabular}


different from the average temperature (weather) in Gresik on the same day which is $29,5^{\circ} \mathrm{C}$ (Meteorology Climatological and Geophysical Agency, 2018). Based on the Minister of Manpower of the Republic of Indonesia (2018) about occupational health and safety work environment, these results exceed the Threshold Limit Value (TLV) which determined the workload and working time arrangements which were $75-100 \%$ (average worker break time is $10 \%$ per hour).

Indonesian people generally can acclimatize the tropical climate where the temperature is around $28-32{ }^{\circ} \mathrm{C}$ with humidity around $85-95 \%$ or more. Acclimatization of climate (weather) can be interpreted as an adjustment that occurs to someone to the climate (weather) to get used to certain conditions and not experience the adverse effects of the condition (Suma'mur, 2013).

When workers are exposed to the hot environment, they can easily experience symptoms that show signs of discomfort such as the increase of core temperature and heart rate, headache or nausea, and other symptoms of fatigue due to the heat. On repeated exposure to a hot environment (within a certain time) workers will acclimatize, and adapt to the environment and get a beneficial effect for the body. Some adaptation mechanisms include the increase of efficiency of sweating, stabilization of circulation, relatively lower core temperature and heart rate. Therefore, there are no symptoms experienced by workers such as workers who cannot acclimatize (Jacklitsch et al., 2016).

Workers will be able to adapt to the hot climate after 5-7 days and will be a maximum after 12-14 days (Moeljosoedarmo, 2008). Based on the results, the average length of workers work in the $5^{\text {th }}$ warehouse of fabrication area of Bangun Sarana Baja Company is about 6.9 years. The shortest length of working is 1 month (30 days). In these conditions, it can be said that the 5th Warehouse workers has adapted to the climate in the workplace.

\section{Physical Workload}

The workload given to workers is part of the demands of the workers that need to be done. If the demands are greater than the work capacity of workers, it causes overstress that can lead to work-related fatigue (Tarwaka, 2013).

The results showed that there is a significant relationship between physical workload and work-related fatigue with a moderate positive correlation coefficient (0.400).

This research is similar to the research conducted at the mechanic workshop in the district of Minahasa Lumintang, Kawatu and Warouw (2017)and the industry of melinjo chips in Indramayu which mentioned that there is a significant relationship between physical workload and work-related fatigue. Workers receiving heavy workload will be at risk of experiencing work-related fatigue 3,750 times higher than the workers who get mild physical workload level (Ahmad and Amanatun, 2015).

Workers who work in the $5^{\text {th }}$ warehouse of fabrication area Bof angun Sarana Baja Company get a diverse physical workload. The level of work-related fatigue that occurs in the workers increases which is followed by an increase in the level of physical workload received by workers.

The working schedule in fabrication area starts on Monday to Thursday, from 08.00 to 17.00 with one hour break starting at 12:00. On Friday, they start from 08:00 to 17:30 pm with 1.5-hours break at 11:30. There is no rhythm of work or setting of rest period (excluding breaks above). Workers do occasional break by themselves around the workplace.

In the normal production, fabrication area makes products using steel as the material. When there is mobility of raw materials in the production process, workers use forklifts and Over Head Crane (OHC) to move very heavy steel. Then, for a small-sized steel, they use stroller or lift it manually. Variations of physical workload received by workers which were done in the $5^{\text {th }}$ warehouse were various depending on the project that is being done.

Physiologically, all forms of activities carried out by workers are the result of the mechanism of the systems in the body through the coordination and the command mechanisms regulated by the central nervous system in the brain. When the activities are large, the energy needed is also large. On the contrary, if the work activities are small, the energy that is expended is also relatively small (Tarwaka, Bakri and Sudiajeng, 2004).

The Physical workload is an employment activity that determines how long a person can work or able to work in accordance to its working capacity. The increase of heavy physical workload that is received will impact on the physiological burden of the workers. 
This will impact on the shortening time for someone to be able to work without making mistakes or without getting health problems. Heavy physical work is characterized by a large physical exertion. Since a lot of energy is consumed in a relatively short time; muscles, cardiovascular system, lungs, and others have to work very hard. As a consequence, heavy physical work can not be forced to work continuously for a relatively long time since jobs have a regular physical workload. As a result, working rhythm arrangements must be made to regulate theshort breaks for all heavy physical work activities (Suma'mur, 2013). The amount of rest time in the company must be determined well. In the theory, break time given to workers between the working time is at least $15-30 \%$ of the entire working time (Tarwaka, Bakri and Sudiajeng, 2004), Workers should receive a break for about 1.2 to 2.4 hours. However, it will be difficult to be applied since it is related to the productivity that should be achieved by the company.

In addition, any work activity requires energy. Work-related fatigue can occur due to the reduced energy that reserves and the residual that is released in blood circulation. The heavier the work done, the greater the energy released. If workers get a lack of energy, the work capacity will be disrupted. Heavy work demands that exceed the capacity of workers will have an impact on overstress; thus, it causes the occurrence of fatigue (Maurits, 2010) (Tarwaka, 2013) .

\section{CONCLUSION}

Based on this study, it can be concluded that the working climate does not have a significant relationship with work-related fatigue. Then, physical workload has a relationship with the work-related fatigue experienced by workers. The heavier physical workload given will be followed by the increase of work-related fatigue level.

\section{ACKNOWLEDGEMENT}

This research cannot be completed without the support of various parties. Thanks God, my parents, lecturers, leaders and the family of the Bangun Sarana Baja Company. May Allah repay every good thing that has been given to the researchers.

\section{REFERENCES}

Adi, D. P. G. S., Suwondo, A. and Lestyanto, D. (2013) 'The Correlation between Working Climate and Nutrient Intake before Working on the Fatigue Level of the Morning Shift Workers on Packing Division of PT.X, Kendal', Jurnal Kesehatan Masyarakat FKM Undip, 2(2), pp. 1-11.

Ahmad, S. and Amanatun, A. (2015) 'The Workload with Fatigue Work in Industrial Workers Melinjo Chips in the Village of Benda Indramayu', Jurnal Kesehatan Masyarakat AFIASI, 1(3), pp. 25-30.

Anna, D. H. (2011) 'The Occupational Environment - Its Evaluation, Control, and Management', in 3rd Edition. Virginia: AIHA.

Herusasongko, B., Sutomo, A. H. and Sudibyakto, H. (2012) 'Effects of the Occupational Physical Environmental Conditions and the Individual Characteristics of the Workers on Occupational Stress and Fatigue', International Journal of Public Health Science, 1(2), pp. 61-68.

Ho, J. C. et al. (2013) 'Work-Related Fatigue among Medical Personnel in Taiwan', Journal of the Formosan Medical Association, 112(10), pp. 608-615.

Jacklitsch, B. et al. (2016) 'Criteria for a Recommended Standard: Occupational Exposure to Heat and Hot Environments'. Ohio: Department of Health and Human Services, Centers for Disease Control and Prevention, National Institute for Occupational Safety and Health.

Krisanti, R. D. (2011) Relation between Pressure Heat with Work Fatigue on Worker Production Section in CV Rakabu Furniture Surakarta. Surakarta: Faculty of Medicine, Universitas Sebelas Maret.

Lemeshow, S. et al. (1997) Adequacy of Sample Size in Health Studies. Edited by P. Dibyo. Yogjakarta: Gajah Mada University Press.

Lumintang, M. F., Kawatu, P. A. T. and Warouw, F. (2017) 'Relationship between Age and Workload with Work Exhaustion of Workshop Mechanic in Kiawa Raya Village, North Kawangkoan District, Minahasa regency', Jurnal Universitas Sam Ratulangi Manado, 9(3), pp. 1-9.

Marif, A. (2013) Factors Associated with Fatigue on Construction Workers 
Offshore Pipeline and Mooring Tower (EPC3) in Banyu Urip Project, PT Rekayasa Industri, Serang-Banten 2013. Undergraduate Thesis. Jakarta: Faculty of Medicine and Health Science, Universitas Islam Negeri Syarif Hidayatullah.

Maurits (2010) Glance about Fatigue Work. Yogjakarta: Amara Books.

Meteorology Climatological and Geophysical Agency (2018) Daily Climate Data of Gresik Regency, Jakarta: Meteorology Climatology and Geophysical Agency.

Minister of Manpower of the Republic of Indonesia (2018) Number 5 Year 2018. Concerning Occupational Safety and Health Work Environment. Jakarta: Ministry of Manpower Republic of Indonesia.

Moeljosoedarmo, S. (2008) Higiene Industri. Jakarta: Balai Penerbit FKUI.

National Safety Council (2017) Fatigue in Safety-Critical Industries: Impact, Risks and Recommendations. Washington, DC: National Safety Council.

O'Neill, C. and Panuwatwanich, K. (2013) 'The Impact of Fatigue on Labour Productivity: Case Study of Dam Construction Project in Queensland', in International Conference on Engineering, Project, and Production Management, pp. 993-1005.

Ricci, J. A. et al. (2007) 'Fatigue in the U.S. Workforce: Prevalence and Implications for Lost Productive Work Time', Journal of Occupational and Environmental Medicine, 49(1), pp. 1-10.

Ristiyanto, F. (2009) Relationship between Heat Climate Exposure to Work Overview after Working in the Boiler Unit PT. Tiga Pilar Sejahtera Food, Tbk Sepat, Masaran, Sragen, Jawa Tengah. Undergraduate Thesis. Surakarta: Faculty of Medicine, Universitas Sebelas Maret.

Safe Work Australia (2013) Guide for Managing the Risk of Fatigue at Work. Australia: Safe Work Australia.

Setyowati, D. L., Shaluhiyah, Z. and Widjasen, B. (2014) 'Factors Caused Fatigue among Furniture Workers', Jurnal Kesehatan Masyarakat Nasional, 8(8), pp. 386-392.

Statistic Indonesia (2016) Indonesian Economic Growth in 2015. Jakarta: Statistic Indonesia.

Suma'mur (2013) Corporate Hygiene and Occupational Health (Hiperkes). Edisi 2. Jakarta: Sagung Seto.
Tarwaka (2013) Industrial Ergonomics: Basics of Ergonomics Knowledge and Applications at Work. Surakarta: Harapan Press.

Tarwaka, Bakri, S. H. A. and Sudiajeng, L. (2004) Ergonomics for Safety, Occupational Health and Productivity. 1st edn. Surakarta: UNIBA Press. 